\title{
Analisis Kepatuhan Wajib Pajak Kendaraan Bermotor dalam upaya Meningkatkan Penerimaan Pajak Daerah pada Kantor Bersama Samsat Jakarta Timur Tahun 2015-2018
}

\author{
Abharina Avidaniar Bintary ${ }^{1} *$ \\ ${ }^{1}$ Institut Ilmu Sosial dan Manajemen STIAMI, Jakarta, Indonesia \\ 1 abharina@gmail.com \\ * corresponding author
}

\section{ARTICLE INFO}

\section{Keywords}

Motor Vehicle Tax, Regional

Tax Revenue, Taxpayer Compliance

\begin{abstract}
$A B S T R A C T$
This study aims to determine the compliance of motor vehicle taxpayers and to find out the obstacles, stimulus, and strategies that are carried out in increasing local tax revenues in East Jakarta's One Roof System (Samsat). The research method is a Qualitative approach with descriptive research type. The results of the study on Compliance in East Jakarta Samsat are fairly good, this is supported by indicators from research such as good registration because taxpayers have followed and know the procedures well, the reports carried out by East Jakarta samsat are in accordance with the specified schedule, Payment of taxpayers in Samsat is fairly good with increasing taxpayers obeying each year in 2018 the highest percentage of compliant taxpayers reaching $60 \%$ with taxpayers totaling 1,296,666 but arrears in tax payable in East Jakarta are quite high in 2017 the amount of arrears from Taxes Motorized vehicles reached Rp. 90,568,276,707, - however, the realization of motor vehicle tax revenues has reached its target each year. Obstacles to the existence of taxpayers are not compliant because Taxpayers' awareness is still lacking due to busyness causing negligence and forgetting to carry out tax obligations and online payment processes are constrained by the lack of understanding of taxpayers about ESamsat, while other obstacles are due to Taxpayer Data which is not appropriate, taxpayers who postpone payment of tax fines are waiting for the elimination of administrative fines so that the efforts made by East Jakarta Samsat provide strict sanctions to taxpayers who do not pay motor vehicle tax, provide taxpayers in paying taxes, and carry out programs elimination of administrative fines.
\end{abstract}

\section{PENDAHULUAN}

Pajak merupakan sumber penerimaan Negara yang terbesar disamping penerimaan non pajak. Sebagai sumber penerimaan yang terbesar maka dari itu pajak harus dikelola dengan baik agar penerimaannya dapat maksimal. Salah satunya yaitu dengan adanya kebijakan pajak yang merupakan sarana dalam mengatur hal terkait dengan perpajakan. Dalam pelaksanaannya kebijakan perpajakan harus didukung dengan kualitas administrasi pajak yang baik. Administrasi Pajak itu sendiri adalah suatu proses kegiatan yang diperlukan untuk melaksanakan berbagai fungsi perpajakan yang mengacu kepada hukum pajak untuk menunjang tujuan sistem perpajakan. Fungsi administrasi pajak merupakan sarana untuk mengontrol perilaku kegiatan atau ukuran kepatuhan (compliance) Wajib Pajak dan kinerja aparat pajak.

Salah satu Pajak Daerah yang dipungut pemerintah daerah dari rakyat adalah Pajak Kendaraan Bermotor (PKB). Pengenaan Pajak Kendaraan Bermotor (PKB) di provinsi DKI Jakarta Nomor 2 Tahun 2015 tentang perubahan Peraturan Daerah Nomor 8 Tahun 2010 tentang Pajak Kendaraan Bermotor (PKB). Kendaraan bermotor adalah semua kendaraan beroda berserta gandengannya yang digunakan di semua jenis jalan darat, dan digerakkan oleh peralatan teknik berupa motor atau peralatan lainnya yang berfungsi untuk mengubah suatu sumber daya energi tertentu menjadi tenaga bergerak kendaraan bermotor yang bersangkutan, termasuk alat berat dan alat besar yang dalam operasinya mengunakan roda dan motor yang tidak melekat secara permanen serta kendaran bermotor yang dioperasikan di air.

Pajak Kendaraan Bermotor (PKB), dipungut pajak atas kepemilikan dan/atau penguasaan kendaraan bermotor. Kendaraan bermotor telah menjadi sarana transportasi yang dibutuhkan masyarakat saat ini. Selain 
itu, akses jalanan dan adanya persekutuan dagang yang menjual kendaraan bermotor dengan cara kredit memicu masyarakat untuk memiliki kendaraan bermotor.

Kepatuhan pajak adalah dimana wajib pajak memenuhi kewajiban perpajakannya dan melaksanakan hal perpajakan dengan baik dan sesuai dengan undang-undang pajak yang berlaku. Kepatuhan pajak merupakan salah satu penunjang yang bisa mampu meningkatkan Pendapatan Asli Daerah. Jumlah kendaraan bermotor setiap tahunnya pasti akan terus meningkat sehingga diharapkan kepatuhan wajib pajak juga meningkat. Tingkat kepatuhan wajib pajak dipengaruhi oleh beberapa faktor, salah satunya adalah kesadaran wajib pajak, kesadaran masyarakat yang tinggi akan mendorong kewajibannya untuk mendaftarkan diri sebagai wajib pajak, melaporkan dan membayar pajaknya dengan benar.

Dari tahun ke tahun angka produksi kendaraan bermotor dalam negeri mengalami kenaikan terus menerus dan ini berarti bahwa jumlah kepemilikan kendaraan bermotor juga semakin meningkat. Meningkatnya jumlah kepemilikan kendaraan bermotor, mengakibatkan terjadinya peningkatan penerimaan di sektor Pajak Kendaraan Bermotor (PKB). Berdasarkan penelitian yang penulis ambil pada tahun 2015 sampai 2018 terdapat fenomena, Seperti terlihat pada tabel I.1. hal tersebut terkait dengan rencana penerimaan Pajak Kendaraan Bermotor dan data penerimaan Pajak Kendaraan Bermotor (PKB) di DKI Jakarta.

\section{Tabel 1. Penerimaan Pendapatan Pajak Kendaraan Bermotor (PKB) DKI Jakarta}

Tahun Anggaran 2015 sampai 2018

\begin{tabular}{|l|l|l|l|l|}
\hline No & $\begin{array}{l}\text { Tahun } \\
\text { PKB }\end{array}$ & $\begin{array}{l}\text { Rencana } \\
\text { Penerimaan PKB }\end{array}$ & $\begin{array}{l}\text { Data Penerimaan } \\
\text { PKB }\end{array}$ & $\%$ \\
\hline 1 & 2015 & 6.050 .000 .000 .000 & 6.090 .200 .500 .774 & $101 \%$ \\
\hline 2 & 2016 & 7.050 .000 .000 .000 & 7.143 .530 .355 .999 & $101 \%$ \\
\hline 3 & 2017 & 7.900 .000 .000 .000 & 7.996 .060 .000 .000 & $101 \%$ \\
\hline 4 & 2018 & 8.350 .000 .000 .000 & 8.552 .500 .000 .000 & $102 \%$ \\
\hline
\end{tabular}

Sumber : http://data.jakarta.go.id

Dari tabel tersebut terlihat persentase penerimaan pendapatan Pajak Kendaraan Bermotor (PKB) DKI Jakarta dari tahun 2015 sampai 2017 cenderung stabil tidak ada peningkatan persentase, kecuali persentase tahun 2018 mengalami peningkatan sebesar 1\% (satu persen), hal ini disebabkan karena meningkatnya jumlah kendaraan bermotor setiap tahunnya. Walaupun data penerimaan pajak kendaraan bermotor sudah mencapai rencana penerimaan pajak tetapi SAMSAT DKI berupaya melakukan penagihan kewajiban kepada pemilik kendaraan yang masih punya tunggakan pajak dengan membuat surat imbauan yang berisikan agar seluruh wajib pajak melunasi kewajibannya membayar pajak kendaraan bermotor. Semakin banyak jumlah wajib Pajak Kendaraan Bermotor (PKB), seharusnya diiringi dengan peningkatan kepatuhan wajib Pajak Kendaraan Bermotor (PKB). kepatuhan pajak yang tidak meningkat akan mengancam upaya pemerintah untuk meningkatkan penerimaan pajak daerah. Untuk menunjang kelancaran proses pemungutan Pajak Kendaraan Bermotor (PKB) demi meningkatkan penerimaan Pajak Daerah maka harus diimbangi dengan usaha-usaha yang lebih efisien. Sehingga mendorong pemerintah mengoptimalkan pelayanan dalam pembayaran pajak.

Fenomena yang penulis dapat dari pra wawancara penelitian dengan informan dari Badan Pajak dan Retribusi Daerah (BPRD) DKI Jakarta adalah masih ribuan kendaraan di Jakarta yang menunggak Pajak Kendaraan Bermotor (PKB), mengingat masih banyaknya wajib pajak yang tidak membayar pajak, Sehingga pihaknya melakukan penyisiran penunggak pajak kendaraan bermotor dengan melakukan berbagai cara untuk mencapai target penerimaan pajak daerah agar terhindar dari potensi kerugian, yaitu dengan memberikan layanan untuk memudahkan masyarakat membayar pajak, diantaranya pelayanan yang dilakukan oleh kantor SAMSAT DKI Jakarta yaitu SAMSAT Induk, SAMSAT Drive Thru, SAMSAT Keliling, Gerai SAMSAT, SAMSAT Kecamatan, e-SAMSAT dan SAMSAT online nasional dan yang paling baru SAMSAT Digital. Pelayanan SAMSAT tersebut memiliki fungsi yang berbeda-beda, dengan adanya banyak layanan tersebut maka akan membantu dan memudahkan masyarakat untuk mengetahui informasi, pembayaran Pajak Kendaraan dan pengurusan yang lainnya.

Berdasarkan fenomena pada penjelasan diatas, terdapat fenomena rendahnya kesadaran dan kepatuhan pembayaran Pajak Kendaraan Bermotor (PKB) yang mengakibatkan masih banyaknya tunggakan pajak kendaraan bermotor di Jakarta. Maka dari itu peneliti akan melihat kepatuhan secara lebih luas dari SAMSAT Jakarta Timur dalam upaya meningkatkan penerimaan Pajak Daerah. 


\section{Tujuan Penelitian}

Berdasarkan latar belakang penelitian diatas, maka tujuan dari penelitian ini adalah:

1. Untuk menganalisis kepatuhan wajib Pajak Kendaraan Bermotor (PKB) pada SAMSAT Jakarta Timur tahun 2015-2018.

2. Untuk menganalisis entitas-entitas apa saja yang menjadi penghambat kepatuhan wajib Pajak Kendaraan Bermotor (PKB) dalam upaya meningkatkan penerimaan Pajak Daerah pada SAMSAT Jakarta Timur tahun 2015-2018.

3. Untuk menganalisis entitas-entitas apa saja yang menjadi pendorong kepatuhan wajib Pajak Kendaraan Bermotor (PKB) dalam upaya meningkatkan penerimaan Pajak Daerah pada SAMSAT Jakarta Timur tahun 2015-2018.

\section{KAJIAN LITERATUR}

\section{Pajak}

Adriani (Halim et al, 2014: 2), mengemukakan pendapatanya mengenai pajak yaitu: Pajak adalah iuran kepada Negara (dapat dipaksakan) yang terutang oleh yang wajib membayarnya menurut peraturan-peraturan, dengan tidak mendapat prestasi kembali, yang langsung dapat ditunjukkan dan yang gunanya adalah untuk membiayai pengeluaran-pengeluaran umum berhubungan dengan tugas Negara yang menyelenggarakan pemerintahan.

\section{Fungsi Pajak}

Menurut Resmi (2014: 3) terdapat dua fungsi pajak yaitu:

a. Fungsi Budgetair (Sumber Keuangan Negara)

b. Fungsi Regularend (Pengaturan)

c. Asas Pemungutan Pajak

\section{Sistem Pemungutan Pajak}

Menurut Sari (2013: 78-79) sistem pemungutan pajak adalah sebagai berikut:
a. Official assessment system
b. Self Assessment System
c. With Holding System

\section{Asas Pengenaan Pajak}

Menurut Resmi (2014: 10) terdapat tiga asas pemungutan pajak yaitu::
a. Asas Domisili (Asas Tempat Tinggal)
b. Asas Sumber
c. Asas Kebangsaan

\section{Pajak Daerah}

Mardiasmo (2016:14), mengemukakan pendapatan nya mengenai pajak daerah, yaitu:

Pajak daerah yang selanjutnya disebut pajak, adalah kontribusi wajib kepada daerah yang terutang oleh orang pribadi atau badan yang bersifat memaksa berdasarkan Undang-undang, dengan tidak mendapatkan imbalan secara langsung dan digunakan untuk keperluan Daerah bagi sebesar-sebarnya kemakmuran rakyat.

Menurut Damas Dwi Anggoro (2017: 18), Pendapatan Asli Daerah adalah merupakan daearah atas pelaksanaan kegiatan pemerintahan dan pelayanan kepada masyarakat, serta pemanfaatan sumber daya yang dimiliki pemerintah daerah, pendapatan ini sering kali dijadikan indikator tingkat kemajuan suatu daerah. Daerah yang dianggap maju adalah daerah yang memiliki pendapatan asli daerah yang tinggi.

Yang dimaksud dengan Pendapatan Asli Daerah adalah pendapatan daerah yang bersumber dari hasil:

a. Pajak Daerah

b. Hasil retribusi daerah

c. Hasil pengelolaan kekayaan daerah yang dipisahkan

d. dan lain-lain Pendapatan Asli Daerah yang sah, yang bertujuan untuk memberikan keleluasaan kepada daerah dalam menggali pendanaan dalam pelaksanaan otonomi daerah sebagai perwujudan asas desentralisasi. 


\section{Pajak kendaraan Bermotor}

Menurut Siahaan (2016: 175), Pajak Kendaraan bermotor adalah Pajak atas Kepemilikan dan atau penguasaan kendaraan bermotor. kendaraan bermotor adalah semua kendaraan beroda beserta gandengannya yang digunakan di semua jenis jalan darat, dan digerakkan oleh peralatan teknik berupa motor atau peralatan lainnya yang berfungsi untuk mengubah suatu sember daya energy tertentu menjadi tenaga gerak kendaraan bermotor yang bersangkutan, termasuk alat-alat berat dan alat-alat besar yang dalam operasinya menggunakan roda dan motor dan tidak melekat secara permanen serta kendaraan bermotor dioperasikan di air.

\section{Objek Pajak Kendaraan Bermotor}

Menurut Siahaan (2016: 180), Objek pajak Kendaraan Bermotor adalah kepemilikan dan atau penguasaan kendaraan bermotor.

\section{Subjek Pajak dan Wajib Pajak Kendaraan Bermotor}

Menurut Siahaan (2016: 182), Subjek pajak Kendaraan Bermotor adalah orang pribadi atau badan yang memiliki dan atau menguasai kendaraan bermotor. sementara itu yang menjadi wajib pajak adalah orang pribadi atau badan yang memliki kendaraan bermotor.

\section{Dasar Pengenaan, Tarif dan Cara Perhitungan Pajak Kendaraan Bermotor}

Menurut Marihot P. Siahaan (2016: 182-186)

1. Dasar Pengenaan Pajak Kendaraan Bermotor

Dasar Pengenaan Pajak Kendaraan Bermotor dihitung sebagai perkalian dari dua unsur pokok, yaitu;

a) Nilai Jual Kendaraan Bermotor (NJKB

b) Bobot

2. Tarif Pajak Kendaraan BermotorBesarnya tarif Pajak Kendaraan Bermotor untuk Kendaraan bermotor Pribadi ditetapkan sebagaimana di bawah ini.

a) Untuk kepemilikan kendaraan bermotor pertama paling rendah sebesar 1\% (satu persen) dan paling tinggi sebesar $2 \%$ (dua persen).

b) Untuk kepemilikan kendaraan bermotor kedua dan seterusnya tarif dapat ditetapkan secara progresif paling rendah sebesar 2\% (dua persen) dan paling tinggi sebesar 10\% (sepuluh persen).

c) Kepemilikan kendaraan bermotor didasarkan atas nama dan atau alamat yang sama.

3. Perhitungan Pajak Kendaraan Bermotor

Besarnya pokok pajak kendaraan bermotor yang terutang dihitung dengan cara mengalikan tarif pajak dengan dasar pengenaan pajak. Secara umum, perhitungan Pajak Kendaraan Bermotor adalah sesuai dengan rumus berikut:

$$
\begin{aligned}
\text { Pajak Terutang } & =\text { Tarif Pajak } \times \text { Dasar Pengenaan Pajak } \\
& =\text { Tarif Pajak } x \text { (NJKB x Bobot) }
\end{aligned}
$$

\section{Saat Terutang, Masa Pajak, dan Wilayah Pemungutan Pajak}

Menurut Siahaan (2016: 187), pajak yang terutang merupakan Pajak Kendaraan Bermotor yang harus dibayar oleh wajib pajak pada suatu saat, dalam masa pajak, atau dalam tahun pajak menurut ketentuan peraturan daerah tentang pajak kendaaraan bermotor yang ditetapkan oleh pemerintah daerah provinsi setempat saat pajak terutang dalam masa pajak terjadi pada saat pendaftaran kendaraan bermotor.

Pada Pajak Kendaraan bermotor, pajak terutang dikenakan untuk masa pajak dua belas bulan berturutturut terhitung mulai saat pendaftaran kendaraan bermotor.

Pajak Kendaraan Bermotor dipungut di wilayah provinsi tempat kendaraan bermotor terdaftar. Hal ini terkait dengan kewenangan.pemerintah provinsi yang hanya terbatas atas kendaraan bermotor yang terdaftar dalam lingkup wilayah administrasi.

\section{Teori Penerimaan Pajak (Revenue Productivity)}

Teori ini memiliki 2 (dua) prinsip menurut Fritz Neumark dalam buku Pohan (2017: 49), yakni:

a. Priciple of adaptability

b. Principle of adequency

\section{Kepatuhan Wajib Pajak}

a. Pengertian Kepatuhan Wajib Pajak 
Menurut Safri Nurmantu (2003: 148) mengatakan bahwa “. Kepatuhan perpajakan dapat didefinisikan sebagai suatu keadaan di mana Wajib Pajak memenuhi semua kewajiban perpajakan dan melaksanakan hak perpajakannya."

b. Macam-Macam Kepatuhan

Menurut Safri Nurmantu (2003: 148-149) dikenal dua macam kepatuhan, yaitu:

1. Kepatuhan Formal

2. Kepatuhan Material

c. Pendekatan Kepatuhan

Pendekatan kepatuhan menurut Chairil Anwar Pohan (2017: 158) dapat ditelurusuri melalui dua pendekatan, yaitu:

1. Faktor Ekonomi

a) Beban keuangan

b) Biaya kepatuhan.

c) Disinsentif.

d) Insentif.

2. Faktor Perilaku

a) Perbedaan individu.

b) Asumsi ketidakadilan.

c) Risiko minimal.

d) Pengambilan resiko..

d. Indikator Kepatuhan

Beberapa contoh indikator-indikator yang digunakan di beberapa Negara OECD untuk memantau tingkat kepatuhan wajib pajak, sebagaimana dikutip oleh Pohan (2017: 160)

1. Pendaftaran

2. Penyampaian SPT

3. Pelaporan yang benar

4. Pembayaran

Dalam hal ini dapat terlihat bahwa Indikator No. 1 dan 2 berhubungan dengan kepatuhan formal sedangkan indikator no. 3 dan 4 berhubungan dengan kepatuhan material.

\section{METODE PENELITIAN}

\section{Pendekatan dan Jenis Penelitian}

Dalam sebuah penelitian diperlukan sebuah metode, penelitian ini penulis menggunakan metode kualitatif dengan pendekatan deskriptif, karena penulis mempertimbangkan fakta, fenomena dan keadaan yang terjadi saat ini.

Menurut Sutomo (2012: 5) penelitian kualitatif adalah penelitian yang menghasilkan data deskriptif berupa kata-kata tertulis atau lisan dari orang atau perilaku tang diamati, penelitian kualitatif merupakan tradisi tertentu dalam ilmu pengamatan manusia dalam kawasannya sendiri yang berhubungan dengan orang-orang.

Jenis penelitian yang penulis gunakan dalam penelitian ini adalah penelitian deskriptif. Menurut Neuman (sofia, 2016: 44), menyatakan bahwa penelitian deskriptif (descriptive research) penelitian yang tujuan utamanya adalah untuk "memberikan gambaran" dengan menggunakan kata-kata dan angka serta untuk menyajikan profil (persoalan), klasifikasi jenis, atau garis besar tahapan guna menjawab pertanyaan seperti siapa, kapan, dimana, dan bagaimana.

Selain itu penulis juga menggunakan jenis penelitian lapangan (Field Research), Penelitian Terapan (Applied Research) dan Penelitian Kasus (Cases study)

\section{Teknik Pengumpulan Data}

Dalam penulisan ini penulis menggunakan beberapa teknik pengumpulan data untuk mendapatkan data yang dibutuhkan dalam penulisan ini, teknik pengumpulan data yang digunakan oleh penulisan yaitu:
1. Observasi
2. Wawancara
3. Dokumen
4. Triangulasi 


\section{Lokasi Penelitian}

Lokasi diadakan penelitian ini bertempat di Badan Pajak dan Retribusi Daerah tepatnya berada di Jl. Abdul Muis No.66, RT 4/RW 3, petojo sel., gambir, kota Jakarta pusat 10160 dan di Kantor Bersama SAMSAT Jakarta timur di Jl DI Panjaitan No.55 RT 12/6 Cipinang Besar Sel. Jatinegara, Jakarta Timur. Lokasi tersebut merupakan tempat untuk pengambilan data dan wawancara tentang realisasi penerimaan Pajak Kendaraan Bermotor dan Jumlah Wajib Pajak Kendaraan Bermotor yang belum dan sudah terdaftar sebagai wajib pajak di Jakarta Timur.

\section{HASIL PENELITIAN DAN PEMBAHASAN}

\section{Sejarah Singkat Kantor Bersama Jakarta Timur}

Dengan meningkatnya intesitas pelayanan di Kantor Bersama Samsat Metro Jaya dan adanya pengembangan Organisasi Dipenda DKI Jakarta berdasarkan Perda No. 5 Tahun 1983 yang menyatakan terhadap pelayanan pembayaran Pajak Kendaraan Bermotor (PKB) dan Bea Balik Nama Kendaraan Bermotor (BBN-KB) dipecah menjadi 5 (lima) menurut wilayah kotamadya, maka pada tahun 1984/1985 direncanakan pembangunan kantor bersama Samsat yang beralamat di Jalan D.I Panjaitan Kav. 55 Jakarta Timur, yang semula direncanakan untuk pembangunan gedung Kantor Walikota Jakarta Timur.

Pada Tahun Anggaran tahun 1986/1987 Kantor Samsat yang berlokasi di jalan D.I Panjaitan Jakarta Timur mulai dibangun oleh Pemda DKI Jakarta dilengkapi dengan peralatan komputer yang secara Online dapat menghubungkan kegiatannya kepada masing-masing unit terkait dan pada bulan oktober 1992 dioperasikan dengan melakukan pelayanan Pajak Kendaraan Bermotor (PKB), BBN-KB, Jasa Raharja dan Penerbitan STNK bagi pemilik kendaraan bermotor yang berdomisili di wilayah Jakarta Timur.

\section{Data Sekunder} berikut:

Adapun data Sekunder berupa dokumen, laporan dan arsip-arsip yang diperoleh oleh peneliti sebagai

1. Rekapitulasi Rencana dan Realisasi Penerimaan PKB Samsat Jakarta Timur tahun 2015-2018.

Tabel 2. Rencana dan Realisasi Penerimaan PKB Tahun 2015-2018

\begin{tabular}{|c|c|c|c|}
\hline $\begin{array}{c}\text { Tahun } \\
\text { Anggaran }\end{array}$ & $\begin{array}{c}\text { Rencana } \\
\text { Penerimaan } \\
\text { Pajak Kendaraan } \\
\text { Bermotor (PKB) }\end{array}$ & $\begin{array}{c}\text { Realisasi } \\
\text { Penerimaan } \\
\text { Pajak Kendaraan } \\
\text { Bermotor (PKB) }\end{array}$ & Persentase \\
\hline $\mathbf{2 0 1 5}$ & 1.041 .212 .000 .000 & 1.065 .477 .112 .757 & $102 \%$ \\
\hline $\mathbf{2 0 1 6}$ & 1.218 .594 .000 .000 & 1.311 .689 .938 .834 & $108 \%$ \\
\hline $\mathbf{2 0 1 7}$ & 1.576 .995 .000 .000 & 1.599 .670 .714 .938 & $101 \%$ \\
\hline $\mathbf{2 0 1 8}$ & 1.653 .000 .000 .000 & 1.734 .783 .530 .761 & $105 \%$ \\
\hline
\end{tabular}

Sumber: samsat Jakarta Timur

Grafik 1. Rencana dan Realisasi Penerimaan Pajak Kendaraan Bermotor

Samsat Jakarta Timur Tahun 2015-2018

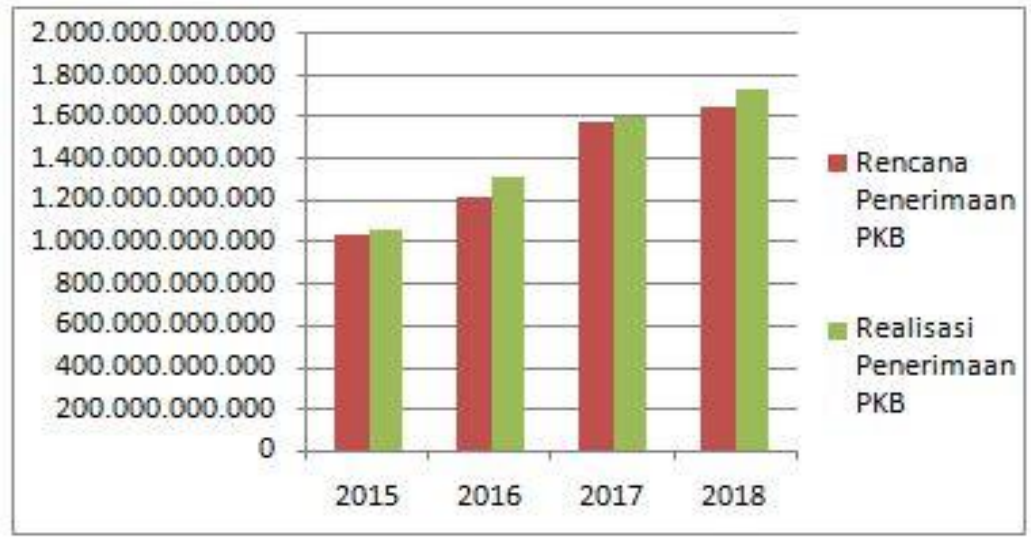

Sumber: data olahan miscrosoft Excel 
Berdasarkan tabel dan grafik di atas dapat diketahui data Rencana dan Penerimaan Pajak Kendaraan Bermotor (PKB) menunjukkan bahwa dari tahun 2015 sampai dengan 2018 realisasi telah mencapai target hal ini disebabkan karena meningkatkan objek dari Pajak Kendaraan Bermotor setiap tahunnya.

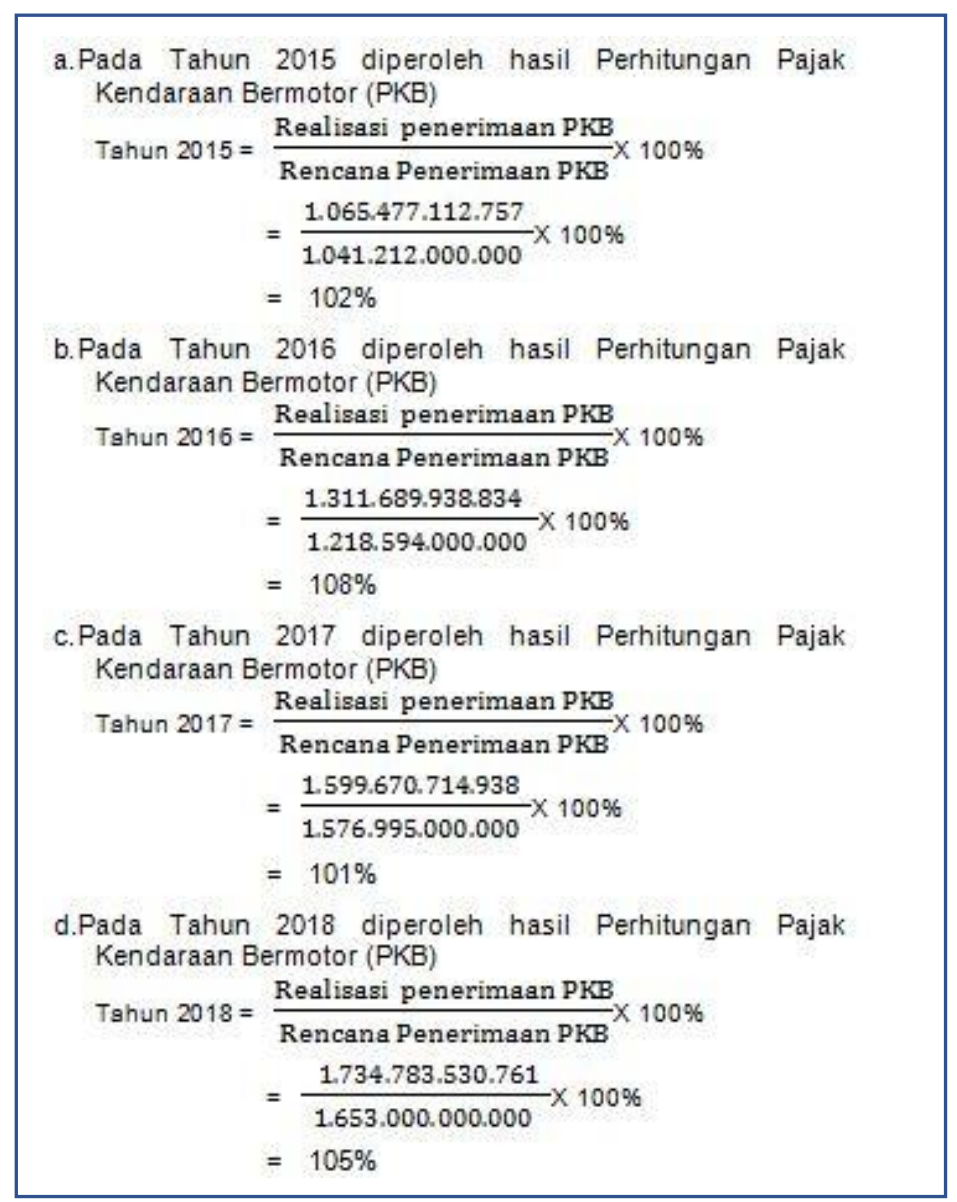

Data dari rencana dan Realisasi Penerimaan Pajak Kendaraan Bermotor (PKB) dari tahun 2015 sampai dengan tahun 2018 Samsat Jakarta Timur meningkat, tetapi terjadinya fluktuasi dimana persentase yang diperoleh cenderung naik turun setiap tahunnya, walaupun demikian penerimaan Pajak Kendaraan bermotor di Samsat Jakarta Timur sudah Baik karena persentase yang diperoleh sudah melebihi $100 \%$.

2. Rekapitulasi Data Wajib Pajak Kendaraan Bermotor yang Terdaftar di Wilayah DKI Jakarta 2015-2018

Tabel 3. Data Wajib Pajak Terdaftar DKI Jakarta 2015-2018

\begin{tabular}{|l|l|l|l|l|l|}
\hline Tahun & BARAT & PUSAT & SELATAN & TIMUR & UTARA \\
\hline 2015 & 2.035 .283 & 1.057 .655 & 1.950 .914 & $\mathbf{2 . 2 4 6 . 1 1 9}$ & 1.407 .093 \\
\hline 2016 & 2.122 .656 & 1.080 .261 & 1.995 .784 & $\mathbf{2 . 4 2 9 . 5 1 2}$ & 1.477 .164 \\
\hline 2017 & 1.131 .581 & 1.532 .460 & 2.214 .971 & $\mathbf{2 . 1 1 1 . 1 4 4}$ & 2.473 .921 \\
\hline 2018 & 1.164 .845 & 1.618 .506 & 2.318 .339 & $\mathbf{2 . 1 4 5 . 9 0 7}$ & 2.628 .949 \\
\hline Total & 6.454 .365 & 5.288 .882 & 8.480 .008 & $\mathbf{8 . 9 3 2 . 6 8 2}$ & 7.987 .127 \\
\hline
\end{tabular}

Sumber: Badan Pajak dan Retribusi Daerah DKI Jakarta

Berdasarkan dari data diatas wajib pajak yang terdaftar yang tercatat di Badan pajak dan Retribusi daerah, pada Kantor Bersama Samsat wilayah Jakarta Timur memiliki jumlah wajib pajak terdaftar yang tertinggi yaitu mencapai 8.932 .682 wajib pajak, hal ini dipengaruhi oleh salah satu faktor yaitu meningkatkan jumlah kendaraan bermotor di Jakarta Timur. 
3. Rekapitulasi Data Penerimaan Wajib Pajak Kendaraan Bermotor pada Samsat Jakarta Timur Tahun 2015-2018

\section{Tabel 4. Data Penerimaan Wajib Pajak Kendaraan Bermotor Samsat Jakarta Timur Tahun 2015-2018}

\begin{tabular}{|l|l|l|}
\hline No & Tahun & $\begin{array}{c}\text { Jumlah Wajib Pajak } \\
\text { Kendaraan Bermotor } \\
\text { (PKB) }\end{array}$ \\
\hline 1 & $\mathbf{2 0 1 5}$ & 1.148 .479 \\
\hline 2 & $\mathbf{2 0 1 6}$ & 1.166 .599 \\
\hline 3 & $\mathbf{2 0 1 7}$ & 1.239 .126 \\
\hline 4 & $\mathbf{2 0 1 8}$ & 1.296 .666 \\
\hline
\end{tabular}

Sumber : Samsat Jakarta Timur

Penelitian ini dilakukan pada Kantor Samsat Jakarta Timur yakni salah satu instansi yang memberikan layanan pengurusan pajak baik kendaraan roda dua maupun kendaraan roda empat. Namun dalam penelitian ini difokuskan pada kendaraan roda dua. Pada tabel diatas bahwa kendaraan bermotor mengalami peningkatan 4 (empat) tahun terakhir dari tahun 2015 yang mencapai 1.148 .479 unit meningkat ditahun 2016 jumlahnya sekitar 1.166 .599 unit dan mengalami peningkatan lagi tahun 2017 sekitar 1.238.126 unit serta mendapatkan peningkatan lagi tahun 2018 sebanyak 1.296.666 unit.

4. Rekapitulasi Data Kendaraan Bermotor roda dua yang dikenakan sanksi administrasi pada samsat jaktim 2015-2018.

\section{Tabel 5. Data Wajib Pajak Kendaraan Bermotor yang dikenakan Sanksi Administrasi Tahun 2015-2018}

\begin{tabular}{|c|c|c|}
\hline No & Tahun & $\begin{array}{c}\text { Jumlah Wajib Pajak } \\
\text { Kendaraan Bermotor } \\
\text { (PKB) }\end{array}$ \\
\hline $\mathbf{1}$ & $\mathbf{2 0 1 5}$ & 231.395 \\
\hline $\mathbf{2}$ & $\mathbf{2 0 1 6}$ & 259.390 \\
\hline $\mathbf{3}$ & $\mathbf{2 0 1 7}$ & 282.879 \\
\hline 4 & $\mathbf{2 0 1 8}$ & 240.016 \\
\hline
\end{tabular}

Sumber: Samsat Jakarta Timur

Berdasarkan tabel di atas menunjukkan peningkatan per 4 (empat) tahun terakhir pada tahun 2015 wajib pajak yang dikenakan sanksi Administrasi mencapai 231.395 unit. Pada tahun 2016 mencapai 259.390 dan pada tahun 2017 mencapai 282.879 unit wajib pajak yang dikenakan sanksi administrasi. Hal ini menunjukkan peningkatan selama 3 tahun karena sangat berpengaruh pada kesadaran wajib pajak dalam membayar pajak kendaraan bermotor dalam tepat waktu, tetapi pada tahun 2018 terjadinya penurunan wajib pajak yang dikenakadministrasi sebesar 240.016 unit.

\section{Pembahasan}

Analisis Kepatuhan Wajib Pajak Kendaraan Bermotor (PKB) dalam Upaya meningkatkan Penerimaan Pajak Daerah pada Samsat Jakarta Timur Tahun 2015-2018

Dalam menganalisis Kepatuhan Wajib Pajak Kendaraan Bermotor (PKB) dalam upaya meningkatkan Penerimaan Pajak Daerah pada Samsat Jakarta Timur pada tahun 2015-2018, penulis mengkajinya menggunakan dua teori yaitu teori kepatuhan OECD dalam Pohan (2017: 160) yang dipengaruhi empat faktor yang terkait dengan kepatuhan yakni Pendaftaran, Pelaporan yang benar, Penyampaian SPT, dan Pembayaran. Selain itu dalam upaya peningkatan penerimaan pajak daerah penulis menggunakan teori penerimaan menurut Fritz Neumark dalam Pohan (2017: 49) yang terdiri dari dua prinsip yakni Prinsip Adequency dan Prinsip Adaptibility.

1. Pendaftaran

Berdasarkan hasil wawancara penulis dengan beberapa informan dapat ditarik kesimpulan bahwa Proses Pendaftaran yang dilakukan oleh Samsat Jakarta Timur kepada wajib pajak untuk melakukan pembayaran pajak kendaraan bermotor cukup memudahkan wajib pajak. Hal tersebut dilihat dari 
wawancara penulis dengan Kepala Unit Samsat dan beberapa Wajib Pajak yang menyatakan persyaratan pembayaran pajak yang diperlukan yaitu STNK, KTP dan BPKB asli maupun fotocopy serta mengisi formulir dan mendatangi Loket yang sudah sesuai. Adapun menurut pakar pajak bapak Heri pendaftaran untuk melakukan pembayaran pajak dapat dilakukan secara online tetapi bapak H. Iwan Syaefudin mengatakan bahwa pembayaran pajak melalui online masih belum maksimal karena masih banyak nya masyarakat yang belum mengetahui tentang internet.

Menurut Bapak H. Iwan Syaefudin (Informan 1) selaku kepala unit Samsat Jakarta Timur memaparkan bahwa: "pertama dia harus melengkapi persyaratan yaitu wp bawa bukti KTP,STNK asli yang mau dibayarkan dan BPKB kemudian WP datang ke Samsat Jaktim, lalu ambil Nomor kemudian dapat notif yang dihitung oleh Bank DKI setelah itu WP bayar Maka STNK sudah bisa Diambil. tetapi yang belom jatuh tempo wp dapat melakukan pembayaran secara mudah ke Drive-Thru jadi wp tidak perlu turun dari kendaraan. Dia tinggal menuju ke Drive Thru yang ada di depan Samsat Jakarta timur dengan persyaratan yang sama. Adapula pembayaran pajak melalui samsat online tetapi ini belum maksimal karena keterbatasan wp yang belum mengetahui mengenai internet jadi masih banyak yang bingung dan belum punya smartphone, walaupun melalui pembayaran online tetapi wp mesti datang kesamsat untuk mengambil STNK dengan dibuktikan Struk pembayaran dari ATM"

Menurut Bapak Heri Puji Trisilo (informan 2) selaku salah satu dosein Pajak Institut STIAMI memaparkan bahwa: Proses pendaftaran untuk membayar pajak sekarang lebih memudahkan wajib pajak kendaraan bermotor untuk membayar pajak, kita bisa datang ke gerai-gerai samsat terdekat atau mengikuti Samsat Keliling dan kita juga bisa membayar pajak melalui online dengan mengikuti saja prosedur yang ada dengan melengkapi persyaratan.

\section{Pelaporan yang benar}

Berdasarkan hasil wawancara penulis dengan beberapa informan dapat ditarik kesimpulan bahwa pelaporam yang diterapakan di samsat, Pelaporannya yang dilakukan melalui sistem canggih atau Online dan perhitungan pajaknya dilihat dari NJKB di STNK. Berdasarkan wawancara penulis kepada Bapak H. Iwan Syaefudin yang menjelaskan mengenai pelaporan yang dilakukan samsat dilakukan setiap sore jam 3 secara online setiap hari.

Menurut (Informan 1) Bapak H. Iwan Syaefudin Kepala Unit Samsat Jakarta Timur memaparkan mengenai pelaporan bahwa sistem pelaporan dasarnya kita mengutip pajak yang terhutang sesuai dengan di STNK, maka kita liat yang di STNK kemudian WP membayar. Hitungan dasarnya adalah NJKB (Nilai Jual Kendaraan bermotor itu ada patokan nya. Ini NJKB juga tim dari departemen dalam negeri, polda metro, BPRD, biro hukum, dan lengkap semuanya hitung dan Tim NJKB berlaku untuk seluruh Indonesia .Dilaporkan setiap hari jam 3 sore online sehingga semua orang bisa lihat kemudian ada laopran bulanan juga

Dari hasil wawancara diatas penulis menyimpulkan bahwa pembayaran pajak yang dilakukan oleh wajib pajak dilakukan di Bank DKI sehingga dananya masuk kedalam Bank DKI kemudia dilaporkan oleh pihak Samsat Jakarta Timur.

3. Pembayaran

Menjawab pertanyaan penulis tentang bagaimana kepatuhan wajib pajak di Samsat Jakarta Timur dalam pembayaran pajak kendaraan bermotor?

Menurut informan 1 mengenai kepatuhan di Samsat Jakarta Timur mengatakan Bahwa kepatuhan pajak pada tahun 2019 saja kurang lebih 70\%, 30\% mereka bukannya tidak patuh tapi mereka bisa dibilang sibuk maka perlunya dengan diadakan razia sebagai informasi agar segera membayar pajak Kendaraan Bermotor.

Menurut penulis kepatuhan di Samsat Jakarta Timur terbilang cukup tinggi dilihat dari persentase wajib pajak yang diperoleh pada tahun 2019, karena penerimaan pajak kendaraan bermotor pada tahun 2015 sampai dengan 2018 saja setiap tahunnya mengalami peningkatan.

\section{Tunggakan}

Berdasarkan pra wawancara penulis dengan informan dari Badan Pajak dan Retribusi Daerah (BPRD) Jakarta yang menyatakan masih ribuan kendaraan di Jakarta yang Menunggak Pajak Kendaraan Bermotor. Berikut data tunggakan yang peneliti peroleh dari Badan Pajak Retribusi Daerah (BPRD): Data Tunggakan PKB per 31 Desember 2016 (2008-2016) adalah sebagai berikit: 
Tabel 6. Data Tunggakan PKB

\begin{tabular}{|c|c|c|c|c|}
\hline No & $\begin{array}{l}\text { Jenis } \\
\text { Pajak }\end{array}$ & \multicolumn{2}{|c|}{$\begin{array}{l}\text { Sisa Piutang tahun } \\
\text { berjalan S.D } \\
\text { Desember } 2016\end{array}$} & $\begin{array}{l}\text { Piutang Audited } \\
\text { S.D } 31 \text { Desember } \\
2016\end{array}$ \\
\hline 1 & PKB & \multicolumn{2}{|c|}{44.018 .770 .650} & 79.063 .988 .854 \\
\hline \multicolumn{5}{|c|}{ Data Tunggakan PKB per 16 Oktober 2017 adalar } \\
\hline No & \multicolumn{2}{|c|}{ Jenis Pajak } & \multicolumn{2}{|c|}{ Jumlah Tunggakan } \\
\hline 1 & \multicolumn{2}{|l|}{ PKB } & \multicolumn{2}{|c|}{90.568 .276 .707} \\
\hline
\end{tabular}

Sumber: Badan dan Retribusi Daerah

Berdasarkan Tabel diatas Tunggakan Pajak pada Tahun 2016 sebesar Rp.79.063.988.854 sedangkan pada tahun 2017 jumlah tunggakan sudah mencapai Rp.90.568.276.707. hal ini terjadi peningkatan yang cukup besar

Menjawab pertanyaan penulis mengenai Bagaimana mengatasi penunggak pajak kendaraan bermotor yang masih banyak di Jakarta?

Menurut (informan 1) Bapak H. Iwan Syaefudin memaparkan dalam mengatasi penunggak pajak dengan cara:

membuat panggilan, jadi yang belum habis kita memberitahuan 1 bulan belum jatuh tempo, setelah habis jatuh tempo kita beri panggilan satu, tidak datang 2 minggu maka kita beri panggilan kedua, tidak datang juga maka akan disamperin ke alamat oleh Samsat kita panggil dengan Door To Door datang ke alamat penunggak pajak, apabila alamat nya tidak sesuai atau penunggak pajak tidak ada langkah yang dilakukan yaitu dengan melakukan Razia dijalan. Bila 5 plus 2 tahun atau 7 tahun wp tidak bayar juga maka kendaraan akan dihapus dari regident

Menurut (Informan 2) dalam mengatasi penunggak pajak yaitu upayanya adalah dilakukannya penempelan-penempelan stiker terhadap kendaraan-kendaraan penunggak. Misalnya di mall kita terjun untuk melihat dan mengecek kendaran-kendaraan yang parkir di mall itu efektif banget artinya kita harus punya data fes kendaraan-kendaraan mana yang kira-kira belum membayar pajak kemudian kita melakukan ke lahan parkir kita cek satu persatu nanti dari nomer saja sudah ketahuan sudah bayar pajak atau belum. Dan kita juga setiap bulan petugas pajak harus mengirimkan surat imbauan kepada penunggak pajak untuk segera melunasi.

Dengan tidak membayar pajak akan menimbukan tunggakan pajak, Adapun jawaban mengenai wajib pajak mengenai Apa yang menyebabkan wajib pajak tidak membayar pajak kendaraan bermotor dengan tetap waktu?

Menurut Informan 4 memaparkan bahwa:

karena kesibukan bekerja, misalnya sudah waktu nya harus membayar pajak tetapi saya sedang diluar kota atau tiba-tiba saya lupa hingga pas ingat ternyata sudah jatuh tempo itu sering sekali terjadi apalgi denda saya juga cukup besar sampai akhirnya keinginan menunggu program pemutihan.

Menurut Infoman 5 Mengatakan Bahwa:

karena uang nya kadang-kadang kurang

Dari hasil wawancara diatas penulis menyimpulkan bahwa Melakukan panggilan agar WP membayar pajak apabila tidak membayar pajak maka akan didatangkan ke alamat penunggak, samsat juga akan melakukan razia guna mengetahui kendaraan yang tidak membayar pajak adapun cara yang dapat digunakan dengan melakukan sosialisasi atau penempelan stiker penunggak untuk membuat rasa malu bagi penunggak, adapun wajib pajak yang tidak membayar pajak dengan tepat waktu disebabkan karena kesibukan dan Faktor ekonomi.

\section{Penerimaan}

Menjawab pertanyaan penulis tentang pengaruh pajak kendaraan bermotor terhadap peningkatan penerimaan pajak daerah?

Menurut informan 1 mengenai pengaruh pajak kendaraan bermotor terhadap peningkatan penerimaan pajak daerah memaparkan bahwa pada tahun 2019 saja 2019 Pendapatan asli daerah untuk daerah Jakarta itu ditarget kan 89 triliun nah untuk BPRD kebagian tugas untuk mencari pajak itu 44 triliun, 
jati separuhnya dari pendapatan asli daerah DKI Jakarta. 5 tahun lebih itu kurang lebih 15 triliun diambil dari pajak kendaarn Bermotor dan dana yang masuk sepenuhnya untuk pembangunan Jakarta, banjir, kebersihan, kesehatan, pendidikan, dan sarana prasarana jalan.

Menurut informan 2 mengenai pengaruh pajak kendaraan bermotor terhadap peningkatan penerimaan pajak daerah memaparkan bahwa Dengan banyaknya kemudahan pembayaran pajak saat ini pajak kendaraan bermotor cukup berpengaruh terhadap penerimaan pajak daerah

Menurut penulis pengaruh Adanya pengaruh mengenai kepatuhan pajak kendaraan bermotor terhadap penerimaan pajak daerah dengan tercapainya target yang sudah ditentukan dan dipengaruhi dengan kemudahan layanan pembayaran pajak sehingga dana yang masuk digunakan untuk kepentingan Negara.

6. Prinsip adabtability

Menjawab pertanyaan penulis tentang Apakah layanan-layanan yang dilakukan oleh Samsat Jakarta Timur sudah cukup fleksibel untuk meningkatkan penerimaan pajak daerah?

Menurut Informan 1 mengenai layanan samsat cukup fleksibel untuk mengingkatkan penerimaan pajak daerah karena dengan diadakannya nya layanan-layanan yang dilakukan samsat contohnya seperti Samsat Keliling memudahkan wajib pajak yang jauh dari kantor samsat sehingga bisa datang ke samsat keliling yang terdekat dari lokasi.

Menurut informan 4 dan 5 mengenai layanan samsat meningkatkan penerimaan pajak daerah cukup baik banyak layanan yang dilakukan samsat sehingga banyak wajib pajak pula yang membayar dengan layanan yang sesuai dengan kita.

Dapat disimpulkan oleh penulis bahwa layanan yang diberikan oleh samsat dalam meningkatkan penerimaan pajak di samsat Jakarta timur terbilang cukup baik.

7. Prinsip adequency

Menjawab pertanyaan penulis mengenai Apakah kontribusi dari Pajak Kendaraan Bermotor samsat Jakarta timur menjamin penerimaan pajak daerah untuk membiayai Kepentingan Negara?

Menurut informan 1 mengatakan bahwa Sangat menjamin Kontribusi nya banyak sekali untuk pembangunan Jakarta, banjir, kebersihan, kesehatan, pendidikan, dan sarana prasarana jalan.

Menurut informan 2 dan 3 mengatakan kontribusi pajak kendaraan bermotor menjamin penerimaan pajak daerah digunakan untuk kepentingan Negara dilihat dari pembangunan infrastruktur dijakarta yang banyak.

Menurut penulis kontribusi pajak kendaraan bermotor menjamin penerimaan pajak daerah digunakan untuk pembangunan Negara

\section{Analisis Kepatuhan wajib pajak Kendaraan Bermotor Pada Samsat Jakarta Timur Tahun 2015-2018.}

Tabel 7. Analisis Kepatuhan Pajak kendaraan Bermotor Samsat Jakarta Timur Tahun 2015-2018

\begin{tabular}{|c|c|c|c|c|c|}
\hline \multirow{2}{*}{ Tahun } & \multirow{2}{*}{$\begin{array}{c}\text { Wajib } \\
\text { pajak } \\
\text { terdaftar }\end{array}$} & \multicolumn{2}{|c|}{ Wajib pajak patuh } & \multicolumn{2}{c|}{ Wajib pajak tidak patuh } \\
\cline { 3 - 6 } & Jumlah & Persentase & Jumlah & persentase \\
\hline 2015 & 2.246 .119 & 1.148 .479 & $51 \%$ & 1.097 .640 & $49 \%$ \\
\hline 2016 & 2.429 .512 & 1.166 .599 & $48 \%$ & 1.262 .913 & $52 \%$ \\
\hline 2017 & 2.111 .144 & 1.239 .126 & $59 \%$ & 872.018 & $41 \%$ \\
\hline 2018 & 2.145 .907 & 1.296 .666 & $60 \%$ & 849.241 & $40 \%$ \\
\hline
\end{tabular}

Sumber : diolah Penulis

Kepatuhan wajib pajak di Samsat Jakarta Timur terbilang sudah baik, terjadinya peningkatan kepada wajib pajak yang patuh setiap tahunnya, persentase tertinggi $60 \%$ untuk wajib pajak patuh, pada tahun 2018 dan $52 \%$ untuk wajib pajak tidak patuh pada tahun 2016.Didasarkan dari wawancara penulis dengan Bapak $\mathrm{H}$. Iwan Syaefudin selaku kepala unit Samsat Jakarta Timur yang menyatakan:

Kepatuhan pajak pada tahun 2019 saja kurang lebih 70\%, sisanya 30\% mereka bisa dibilang bukannya tidak patuh tapi mereka bisa dibilang sibuk maka perlunya dengan diadakan razia sebagai informasi agar segera membayar Pajak Kendaraan Bermotor. 
Adapun pendapat lain dari Ahli pajak Bapak Heri Puji Trisilo mengenai kepatuhan memaparkan bahwa : Kepatuhan cukup tinggi walaupun penunggak pajak dijakarta juga banyak adapun wajib pajak merasa enggan karena jarak untuk pembayaran pajak yang jauh harus ke Kantor SAMSAT, makanya sekarang pemerintah DKI memberikan kemudahan dengan adanya samsat keliling. Sedangkan kesadaran masyarakat itu yang susah terhubung, masyarakat itu agak sulit membayar pajak sebelum jatoh tempo, mepet waktu, kadang-kadang lupa, karena jauh.

Menurut penulis kepatuhan wajib pajak kendaraan bermotor terbilang sudah sangat baik dengan meningkatnya setiap tahun wajib pajak yang membayar pajak kendaraan bermotor kecuali pada 2016 terjadi sedikit penurunan. Wajib pajak yang tidak patuh mengalami penurunan setiap tahunnya kecuali pada tahun 2016 wajib pajak yang tidak membayar mengalami peningkatan disebabkan dengan berbagai faktor dari kesibukan, data wajib pajak penunggak yang kurang akurat, hingga memiliki denda administrasi yang tinggi sehingga wajib pajak menunggu adanya program penghapusan denda administrasi.

Analisis Penerimaan Pajak Daerah Sektor Pajak Kendaraan Bermotor pada Samsat Jakarta Timur Tahun 2015-2018

Tabel 8. Analisis Peningkatan Penerimaan Pajak Kendaraan Bermotor Tahun 2015-2018

\begin{tabular}{|c|c|c|c|c|}
\hline No & Tahun & Realisasi & $\begin{array}{c}\text { Peningkatan } \\
\text { Penerimaan Pajak } \\
\text { Daerah }\end{array}$ & $\begin{array}{c}\text { (Naik/Turun) } \\
\%\end{array}$ \\
\hline 1 & 2015 & 1.065 .477 .112 .757 & - & - \\
\hline 2 & $\mathbf{2 0 1 6}$ & 1.311 .689 .938 .834 & 246.212 .826 .077 & $23 \%$ \\
\hline 3 & $\mathbf{2 0 1 7}$ & 1.599 .670 .714 .938 & 287.980 .776 .104 & $22 \%$ \\
\hline 4 & $\mathbf{2 0 1 8}$ & 1.734 .783 .530 .761 & 135.112 .815 .823 & $8 \%$ \\
\hline
\end{tabular}

Sumber: Samsat Jakarta Timur yang sudah diolah penulis

$$
\begin{aligned}
& \text { Keterangan: } \\
& \text { Tshun } 2016=\frac{1.211 .689 .938 .843-1.065 .477 .112 .757}{1.065 .477 .112 .757} \times 100 \% \\
& =\frac{246.212 .826 .077}{1.065 .477 .112 .757} \times 100 \% \\
& =23 \% \\
& \text { Tahun } 2017=\frac{1.599 .670 .714 .938-1.311 .689 .938 .834}{1.311 .689 .938 .834} \times 100 \% \\
& =\frac{287.980 .776 .104}{1.311 .689 .938 .834} \times 100 \% \\
& =22 \% \\
& \text { Tshun } 2018=\frac{1.734 .783 .530 .761-1.599 .670 .714 .938}{1.599 .670 .714 .938} \times 100 \% \\
& =\frac{135.112 .815 .823}{1.599 .670 .714 .938} \times 100 \% \\
& =8 \%
\end{aligned}
$$

Dapat disimpulkan dari tabel analisis data peningkatan penerimaan pajak kendaraan bermotor mengalam ifluktuasi, pada tahun 2016 peningkatan penerimaan mendapatkan Rp246.212.826.077,-- dengan persentase 23\%, pada tahun 2017 terjadi peningkatan penerimaan pajak kendaraan bermotor sebesar Rp. 287.980.776.104,- dengan persentase $22 \%$ sedangkan pada tahun 2018 terjadi penurunan yang cukup besar yaitu hanya memperoleh tingkat penerimaan Pajak kendaraan bermotor sebesar Rp. 135.112.815.823,dengan persentase yang didapat hanya $8 \%$. Faktor penurunan tingkat penerimaan pajak kendaraan bermotor tersebut disebabkan dengan kesadaran wajib pajak kendaraan bermotor yang masih terbilang cukup rendah didasarkan dengan masih banyaknya penghambat yang disampaikan oleh Bapak H.Iwan Syaefudin dalam wawancara yang dilakukan oleh penulis. 


\section{Entitas penghambat dan Strategi Samsat Jakarta mengenai Kepatuhan Pajak Kendaraan Bermotor dalam upaya meningkatkan Penerimaan Pajak Daerah.}

a. Penghambat

Berdasarkan hasil penelitian penulis,ditemukan adanya berbagai faktor yang menjadi hambatan mengenai kepatuhan wajib pajak kendaraan bermotor dalam penerimaan pajak daerah di samsat Jakarta timur.

Dalam menjawab pertanyaan penulis mengenai hambatan apa saja yang dialami Samsat Jakarta Timur dalam mengatasi wajib Pajak Kendaraan bermotor?

Menurut Informan 1 mengenai penghambat apa saja yang dihadapi yaitu yang pertama data kurang akurat, kedua wajib pajak sudah tidak memiliki kendaraan tersebut karena sudah dijual tetapi tidak lapor sehingga kita buat panggilan tetapi tidak sampai. Ketiga wajib pajak sibuk,lalai karena lupa, keempat mungkin wp menunggu penghapusan denda administrasi

Menurut Informan 2 mengenai Hambatan Samsat Jakarta Timur dalam wajib Pajak Kendaraan Bermotor mengatakan bahwa:

Semakin banyak nya kendaraan bermotor dan pemiliknya yang kadang tidak diketahui alamatnya. Yang kedua pemiliknya tidak sama dengan yang sebenarnya misalnya dia hanya pinjam nama untuk memilik kendaraan bermotor itu yang jadi masalah sehingga semakin banyak menumpuk namanya hutang pajak kendaraan kendaraan bermotor karena itu pemilik aslinya sulit untuk diketahui. kadang-kadang kendaraan bermotor plat Jakarta tetapi kendaraan adanya dijogja karena Jakarta termasuk untuk pasar jual beli kendaraan bermotor itu murah maka banyak yang beli Jakarta jualnya di luar jadi sulit untuk memantau.

Menurut penulis menyimpulan bahwa hambatan yang dialami Samsat Jakarta Timur terhadap kepatuhan Wajib Pajak Kendaraan diantaranya:

1) Data wajib pajak kurang akurat hal ini diakibatkan karena data antara kendaraan bermotor dan pemilik yang tidak sesuai.

2) Wajib pajak sudah tidak memiliki kendaraan tersebut karena sudah dijual tetapi tidak lapor.

3) Wajib pajak mempunyai kesibukan sehingga menyebakan lalai atau lupa, hal ini termasuk kedalam kesadaran wajib pajak kendaraan bermotor yang masih kurang

4) Wajib pajak menunggu adanya program penghapusan denda administrasi, ini merupakan kebiasaan buruk wajib pajak yang menunggak pajak dengan denda yang tinggi sehingga menunggu adanya penghapusan denda administrasi.

5) Kurangnya pemahaman wajib pajak mengenai pembayaran melalui layanan Samsat Online atau eSamsat

b. Strategi

Menjawab pertanyaan penulis mengenai Strategi apa saja untuk mengatasi hambatan-hambatan yang terjadi oleh Samsat Jakarta Timur.

Menurut Informan 1 mengenai Strategi yang dilakukan Samsat Jakarta Timur dalam mengatasi hambatan memaparkan bahwa: pertama kita buat surat panggilan 1.2 dan 3 sebagai surat peringatan. Kedua kita lakukan Door to Door ke alamat penunggak, ketiga kita melakukan Razia dengan Tim dengan membawa media bahkan didampingi oleh KPK, keempat kita melakukan Razia dijalan lalu kita samapian kepada public berupa himbauan melalui media televisi

Menurut Informan 2 mengenai Strategi yang dilakukan Samsat Jakarta Timur untuk wajib pajak kendaraan bermotor memaparkan bahwa:

mensegel kendaraan, menarik kendaraan dari kepemilikan ditahan dulu sementara di daerah dimana dia izin tempat tinggal sehingga dapat memberikan efek jera hingga kendaraan tersebut segera dilunasi maka perlunya tindakan mensita kendaraan

Menurut Penulis berdasarkan wawancara diatas mengenai Strategi yang dilakukan diantaranya yaitu:

1) Membuat surat panggilan pertama apabila selama 2 minggu panggilan tidak dipenuhi maka akan dilakukan surat panggilan kedua selama seminggu tidak dipenuhi juga maka dilakukan surat panggilan terakhir dan selama 3 hari tidak datang, maka langkah selanjutnya pihak kami akan melakukan tindakan tegas.

2) Mendatangi ke alamat penunggak pajak biasanya kita membawa tim media juga agar segera melunasi tunggakan pajak kendaraan bermotor.

3) Melakukan Razia di jalanan dengan membawa media, hal ini dilakukan agar wajib pajak yang tidak melaksanakan perpajakannya diberi efek jera dan rasa malu sehingga setelah itu dapat membayar 
pajak dengan cara seperti ini wajib pajak terpantau dan meningkatkan kesadaran wajib pajak serta menjadikan wajib pajak patuh akan kewajiban perpajakannya

4) Melakukan sita kendaraan tetapi belum dilakukan belum dilakukan oleh Samsat karena bukan wewenang dari Samsat Jakarta untuk menyita kendaraan yang tidak membayar pajak

5) Melakukan sosialisasi mengenai pembayaran samsat online atau dengan menambah petugas sehingga dapat memberikan simulasi mengenai pembayaran online melalui Samsat Online oleh wajib pajak yang berada di Samsat Jakarta Timur dengan dengan waktu yang cukup lama.

Entitas pendorong dan Strategi Samsat Jaktim untuk mempertahakan kepatuhan wajib pajak kendaraan bermotor dalam upaya meningkatkan penerimaan pajak daerah

a. Pendorong

Berdasarkan hasil penelitian penulis mengenai kepatuhan wajib pajak kendaraan bermotor perlunya faktor pendorong yang dilakukan oleh Samsat Jakarta timur guna mempertahankan Wajib Pajak dalam membayar pajak.

Dalam menjawab pertanyaan penulis mengenai Entitas-Entitas pendorong yang membentuk kepatuhan wajib Pajak Kendaraan Bermotor (PKB) dalam upaya meningkatkan penerimaan Pajak Daerah pada SAMSAT Jakarta Timur?

Menurut Informan 1 mengenai pendorong apa saja yang dilakukan oleh Samsat Jakarta Timur yaitu dengan memberikan penghapusan denda administrasi, memberikan kemudahan bagi wajib pajak agar tidak melalui calo

Dapat disimpulkan oleh penulis bahwa faktor pendorong yang dilakukan oleh Samsat Jakarta Timur yakni dengan:

1) Memberikan program pemutihan pajak kendaraan bermotor atau penghapusan denda administrasi pajak kendaraan bermotor sehingga meringkan wajib pajak yang memiliki banyak denda, tetapi pemberlakuan pemutihan pajak kendaraan bermotor tergantung dari kebijakan pemerintah daerah yang dapat memberikan keringanan, pengurangan dan pembebasan pajak terutang, serta denda administrative lainnya.

2) Memberikan layanan-layanan inovasi yang memudahkan wajib pajak seperti tanpa memerlukan bantuan dari Calo

b. Strategi

Menjawab pertanyaan penulis mengenai Strategi apa saja untuk mempertahankan Faktor pendukung guna mempertahankan wajib pajak oleh Samsat Jakarta Timur.

Menurut Informan 1 mengenai Strategi dari entitas pendorong mengatakan bahwa memberikan layanan dengan baik pelayanan Prima dan untuk kendaraan-kendaraan tertentu kita memberikan penghargaan, menurut penulis Strategi digunakan untuk mempertahankan wajib pajak agar membayar pajak kendaraan bermotor dengan tepat waktu, yaitu dengan:

1) Memberikan pendekatan kepada wajib pajak dengan Memberikan arahan atau informasi kepada wajib pajak yang tidak membayar denda pajak agar tidak menunggu program pemutihan pajak kendaraan bermotor atau penghapusan denda administrasi karena program tersebut tidak tentu jadwal terlaksananya sehingga dapat menyusahkan wajib pajak dengan bertambahnya terus denda administrasi setiap bulannya apabila tidak membayar pajak.

2) Memberikan layanan dengan baik yaitu pelayanan prima, tujuan nya yaitu agar wajib pajak merasa nyaman dengan apa yang sudah diberikan oleh Samsat

3) Memberikan penghargaan terhadap kendaraan-kendaraan tertentu dengan mengucapkan terimakasih.

\section{KESIMPULAN}

\section{Kesimpulan}

1. Kepatuhan di Samsat Jakarta Timur terbilang sudah baik hal ini didukung oleh indikator-indikator dari penelitian seperti pendaftaran yang sudah baik karena wajib pajak sudah mengikuti dan mengetahui prosedur dengan baik, pelaporan yang dilakukan oleh samsat Jakarta Timur sudah sesuai dengan jadwal yang ditentukan yaitu setiap hari pada pukul tiga sore, Pembayaran wajib pajak di Samsat terbilang cukup baik dengan meningkatnya wajib pajak patuh setiap tahunnya namun tunggakan pajak terutang di Jakarta Timur terbilang cukup tinggi pada tahun 2017, walaupun demikian, penerimaan realisasi pajak kendaraan bermotor sudah mencapai target setiap tahunnya. Hal ini karena meningkatnya jumlah wajib pajak yang patuh yaitu pada tahun 2018 persentase tertinggi wajib pajak patuh mencapai $60 \%$ 
dengan wajib pajak berjumlah 1.296.666 dan wajib tidak patuh mengalami penurunan pada tahun 2018 dengan persentase $40 \%$ dengan jumlah wajib pajak yang tidak patuh sebanyak 849.241 , hal ini didukung oleh realisasi yang mencapai rencana dari tahun 2015 sampai dengan 2018. Peningkatan penerimaan pajak kendaraan bermotor tertinggi terjadi pada tahun 2016 sampai dengan 2017 yang memperoleh persentase $23 \%$. Walaupun kepatuhan mengalami peningkatan dan realisasi setiap tahun mencapai target tetapi tunggakan pajak kendaraan bermotor terbilang cukup besar pada tahun 2017 jumlah tunggakan Pajak kendaraan Bermotor sebesar Rp. 90.568.276.707,-

2. Entitas penghambat yang dialami oleh Kantor Bersama Samsat Jakarta Timur adalah data wajib pajak yang tidak akurat, kesadaran wajib pajak yang kurang dalam hal faktor ekonomi dan kesibukan menjadi salah satu alasan wajib pajak tidak membayar pajak kendaraan bermotor secara tepat waktu, wajib pajak yang mempunyai denda yang besar sangat menanti adanya program penghapusan denda administrasi dan masih kurangnya sosialisasi mengenai pembayaran melalui Online atau pembayaran dengan ESamsat.

3. Entitas pendorong yang dilakukan oleh Kantor Samsat Bersama.Jakarta timur yaitu memberikan penghapusan denda administrasi ini bertujuan agar wajib pajak segera melunasi pajak kendaraan bermotor tanpa dikenakan denda, memberikan kemudahan bagi wajib pajak mengenai layanan-layanan yang dapat membayar pajak kendaraan bermotor dengan mudah.

\section{Saran}

1. Memberikan Sosialisasi mengenai Samsat Online yang masih belum maksimal sehingga masyarakat yang memiliki kesibukan dapat membayarkan pajak dengan mudah dan juga pembayaran pajak modern dengan tidak datang ke Samsat untuk pembayaran pajak atau pengambilan STNK teruntuk wajib pajak yang memiliki kesibukan.dapat dikirimkan ke alamat wajib pajak.

2. Memberikan efek jera kepada wajib pajak dengan member sanksi tegas kepada wajib pajak yang telah lama tidak membayar pajak kendaraan bermotor dengan dilakukan penempelan stiker ditempat keramaian bagi penunggak pajak melalui pengecekan canggih agar wajib pajak merasa malu.

3. Memberikan penghargaan kepada wajib pajak yang selalu membayar pajak kendaraan bermotor dengan tepat waktu dengan memberikan hadiah-hadiah sebagai wujud terimakasih dari Samsat

\section{DAFTAR PUSTAKA}

\section{Buku-buku:}

Anggoro, Damas Dwi. 2017. Pajak Daerah dan Retribusi Daerah. Malang: UB Press.

Creswell, Jhon . 2009. Menifesto Ekonomi Kerakyatan. Yogyakarta: Pustaka Pelajar.

Darwin. 2010. Pajak Daerah \& Retribusi Daerah. Edisi Pertama. Jakarta: Mitra Wacana Media.

Halim, Abdul et al. 2014. Perpajakan: Konsep, Aplikasi, Contoh, danStudi. Jakarta: SalembaEmpat.

Mardiasmo,2016. Perpajakan Edisi Revisi Revisi 2016. Yogyakarta:Andi Offset.

Meleong,Lexy J.2016.Metode penelitian kualitatif. Bandung: PT. Remadja Rosdakarya

Munir, Darsi et al. 2004. Studi Kebijakan dan Manajemen Keuangan Daerah. Yogyakarta: YPAP.

Nazir, Moh. 2011. Metode Penelitian. Jakarta: Ghalia Indonesia.

Pasolong, Harbani. 2010. Teori Administrasi Publik. Bandung: Alfabeta.

Pohan, Chairil Anwar. 2014. Pembahasan Komprehensif Pengantar Perpajakan Teori dan Konsep Hukum Pajak. Jakarta: Mitra Wacana Media.

Resmi, Siti. 2014. Perpajakan: Teori dan Kasus. Edisi 8. Jakarta: Salemba Empat.

Rosdiana, Hauladan Irianto, Edi Slamet. 2012. Pengantar Ilmu Pajak: Kebijakan dan Implementasi di Indonesia. Jakarta: PT Raja Grafindo Persada.

S, Prianto Budi. 2017. Buku Pintar Pajak. Edisi 2. Jakarta: PT Pratama Indomitra Konsultan.

Samudra, Azhari. 2016. Perpajakan Indonesia keuangan Pajak dan Retribusi Daerah. Jakarta: Rajawali Pers.

Sari, Diana. 2013. Konsep Dasar Perpajakan. Bandung: PT Refika Aditama. 
Siahaan, Marihot Pahala. 2016. Pajak Daerah dan Retribusi Daerah. Cetakan Ketiga. Jakarta: Rajawali Pers. Silaen, Sofar. 2013. Metodologi Penelitian Sosial Untuk Penulis Skripsi Dan Tesis. Jakarta: IN MEDIA. Sugiono. 2013. Metode Penelitian Kuantitatif, Kualitatif Dan R\&D. Cetakan ke-19. Bandung: Alfabeta

\section{Peraturan Perundang-Undangan:}

Undang-Undang Republik Indonesia Nomor 28 Tahun 2009 Tentang Pajak Daerah dan Retribusi Daerah.

Undang-Undang Nomor 36 Tahun 2008 Tentang Ketentuan Umum danTata Cara Perpajakan.

Undang-undang Republik Indonesia No.32 Tahun 2004 tentang Pemerintah Daerah

Peraturan Daerah Nomor 2 Tahun 2015 tentang perubahan Peraturan Daerah Nomor 8 Tahun 2010 tentang Pajak Kendaraan Bermotor. 